\title{
Liturgical guidelines for congregations to have a voice in the serious problem of economical inequality in South Africa
}

Author:

Barend J. de Klerk

Affiliation:

${ }^{1}$ Faculty of Theology, NorthWest University, South Africa

Correspondence to:

Barend de Klerk

Email:

ben.deklerk@nwu.ac.za

Postal address:

PO Box 20764, Noordbrug

2522, South Africa

Dates:

Received: 10 Jan. 2013

Accepted: 11 July 2013

Published: 16 Sept. 2013

How to cite this article: De Klerk, B.J., 2013, 'Liturgical guidelines for congregations to have a voice in the serious problem of economical inequality in South Africa', In die Skriflig/In Luce Verbi 47(1), Art. \#683, 9 pages. http://dx.doi.org/10.4102/ ids.v47i1.683

\section{Copyright:}

C 2013. The Authors. Licensee: AOSIS OpenJournals. This work is licensed under the Creative Commons Attribution License.
It is part of the calling of the church to address issues of justice and peace, and to care for the poor and the marginalised in society, because the church is the body of Christ and therefore the heart and hands of Christ in this world. In this article, the problem statement is: 'How can liturgical guidelines help churches to become involved in the economic inequality and the consequent poverty in our society?' Richard Osmer articulates a practical theological method that is largely employed in this research. South Africa is the world's most unequal nation. The South African economy grew steadily from 1992 to 2008, but the benefits were distributed unequally, such that income inequality actually worsened. It is necessary to get a truthful starting point for the church to address this need - and the best way will be to discover the identity of the church. The church's identity is described in the liturgical sense in three phases of involvement in society, namely (1) the gathering and sending of the local congregation; (2) the liturgical responsibility with the ecumenical church; and (3) the possible cooperation with those who do not share the Christian faith.

Liturgiese riglyne vir kerke om 'n stem te laat hoor in die ernstige probleem van ekonomiese ongelykheid in Suid-Afrika. Deel van die kerk se roeping is om aangeleenthede soos geregtigheid en vrede aan te spreek, asook om vir armes en gemarginaliseerdes in die samelewing te sorg. Die kerk is immers die liggaam van Christus en daarom die hart en hande van Christus in die wêreld. Die probleemstelling van hierdie artikel is: 'Hoe kan liturgiese riglyne kerke help om betrokke te raak by die ekonomiese ongelykhede en gevolglike armoede in die SuidAfrikaanse samelewing?' Richard Osmer bied 'n prakties-teologiese metode wat met vrug gebruik is in hierdie navorsing. Suid-Afrika is die wêreld se mees ekonomies-ongelyke nasie. Die Suid-Afrikaanse ekonomie het van 1992 tot 2008 stelselmatig gegroei, maar die voordele daarvan is sodanig versprei dat die ongelykheid in inkomste toegeneem het. Dit is nodig om 'n betroubare vertrekpunt vir die kerk te vind om hierdie probleem te hanteer - en die beste wyse is om by die identiteit van die kerk aansluiting te vind. Die identiteit van die kerk in die liturgiese sin word in drie fases van betrokkenheid in die samelewing beskryf: (1) die vergadering en uitstuur van die plaaslike gemeente; (2) die liturgiese verantwoordelikheid tesame met die ekumeniese kerk; en (3) die moontlike samewerking met hulle wat nie in die Christelike geloof deel nie.

\section{Introduction}

It is part of the calling of the church to address issues of justice and peace, to care for the weak, the poor and the marginalised in society, and to speak out on their behalf when they cannot achieve that themselves (Pr 31:7; Beukes 2002:2). For the more than 50\% of the population in South Africa who are struggling to survive below the official poverty line, ${ }^{1}$ life in South Africa is not easy, to say the least. If they were able to find the time and energy to formulate the question amidst their daily struggle, they would probably say that the question for them is not so much if God really cares, but how they can experience it. Christian Aid in the UK shows the way with the slogan: 'We believe in life before death' (Beukes ibid:3).

The liturgy may never ignore the context of the South-African society, but at the same time the liturgy is also a 'meaningless game' (Wepener \& Cilliers 2006:791) that believers play coram Deo. However, it remains a very serious game in which God and humans really encounter one another through rituals and symbols by means of a dialogical communication, and therefore a game in which God, through his Spirit, can establish a connection between liturgy and life (Wepener \& Cilliers ibid:791). In this article, the focus is on the context of economical inequality in our society.

1.This minimum level of existence implies that someone has not sufficient means to follow a nutritious diet, cannot afford efficient housing and basic medical services and cannot pay for education. 
Osmer (2008:58) reasons that a reader must be able to spot the background assumptions that influence the way a researcher conducts the research as well as the researcher's findings. This also helps readers to become reflexive about their own research. Osmer (ibid:4) articulates a practical theological method that will largely be employed in this article. His practical theological method involves the consideration of four interrelated 'moments':

1. The descriptive moment: What is going on? What is the extent of economical inequality?

2. The interpretive moment: Why is this going on? Why these inequalities and what are their effects on people?

3. The normative moment: What should be going on? What should the church imply as norms to adjudicate and handle inequality according to its identity?

4. The strategic moment: What should be done? How can liturgical actions guide congregations in this respect?

The research will be mainly conducted by using relevant literature and then critically evaluating and applying it in order to make it relevant.

\section{The descriptive moment: What is going on? What is the extent of the economical inequality?}

In this section of the article, the author will try to give a description of what is taking place in the South African society with regard to economical inequality and the related poverty. The arguments involved and the solution for these serious problems will be stated.

South Africa is the world's most unequal nation, with half the population living in poverty on just $11 \%$ of national income. One measure indicating major structural problems is the so-called Gini coefficient. Measuring social and economic inequality on a scale of $0-1$ (zero implying no inequality) in 2008 South Africa received the highest score in the world at 0.69 (Beukes 2002:2). This indicates that the South African population is the most unequal society in terms of income distribution between rich and poor in the whole world. This spells a problem - a severe economic problem - in South Africa (Beukes ibid:2).

This is hardly surprising. For most of the past century, national policies discriminated vigorously against the majority of the country's population. Amongst other iniquities, people were denied access to decent education, the right to own property and accumulate assets, the right to move freely, and the right of equal access to the labour market. Add to this the labour market protections enjoyed by White South Africans, the heavy spending on education and training of White people and the associated adoption of a capital-intensive economic growth path, and it becomes clear that high levels of inequality were inevitable. In other ways, however, the level of present-day inequality is surprising. Add the aggressive programmes of affirmative action, the billions of Rands spent on Black Economic Empowerment, as well as the sheer weight of voter expectations to the abovementioned inequality, and it is remarkable that the levels of inequality are probably no better than they were in the early 1990s - it may even have worsened (Altbeker, Hay \& Bernstein 2010:3).

When South Africa's first democratically elected government assumed office in 1994, it was faced with widespread poverty. The persistence of poverty despite economic growth, both before and after 1994, was due to the highly unequal distribution of the benefits of growth. This inequality was highly racialised, in that apartheid had ensured that White South Africans had skills, opportunities and high incomes, whilst many Black South Africans lacked skills, faced few opportunities and remained in poverty. Democratisation was accompanied by high hopes that income poverty and inequality would be reduced. The poor were enfranchised, the propoor and pro-Black ANC was elected into office, the deracialisation of public policies was completed and even private practices were subjected to a degree of deracialisation. The ANC promised 'a better life for all' in its 1994 election campaign and its election manifesto (the Reconstruction and Development Programme, or RDP) promised that 'attacking poverty and deprivation' would be 'the first priority of the democratic government' (Asaf et al. 2010:6). Socio-economic rights were also included in the 1996 constitution.

The year 1994 was a time of great promise and great hope, but as the idealism of that time wanes, questions about the transition's concrete results, or lack thereof, are of grave concern. Today, poverty ${ }^{2}$ and inequality remain South Africa's defining feature. Progress has been made. There are now millions more South Africans with access to clean drinking water, the number of households with electricity increased from $50 \%$ to $80 \%$, the banking system started making credit available to the Black underclass, and the Black middle class is expanding (Asaf et al. 2010:5).

However, the outcome after 17 years of democratic government has been disappointing. The reduction of poverty in South Africa requires sustained growth and a more propoor growth path. The South African economy grew steadily from 1992 to 2008 (with the exception of 1998), but the benefits were distributed unequally so that income inequality actually worsened, whilst income poverty in 2008 was little better than in 1994 (Nattrass \& Seekings 2010:5). Poverty in South Africa is rooted in a combination of very high unemployment (at about one-third of the labour force), together with a decline in landowners and subsistence agriculture. Poverty is mitigated by a highly redistributive welfare system, but any further reduction in poverty requires reducing unemployment amongst the currently unskilled. This in turn requires a combination of enhancing skills, on the one hand, and expanding the demand for unskilled labour on the other (Nattrass \& Seekings ibid:5).

2.Poverty has various manifestations, including lack of income and productive resources sufficient to ensure sustainable livelihoods, hunger and malnutrition, ill health limited or lack of access to education and other basic services, increased morbidity limited or lack of access to education and other basic services, increased morbidity and mortality from illnesses, homelessness and inadequate housing, unsafe environments and social discrimination and exclusion. It is also characterised by lack of participation in decision-making and in civil, social and cultural life. Absolut poverty is a condition characterised by severe deprivation of basic human needs, including food, safe drinking water, sanitation facilities, health, shelter, education, and information. It depends not only on income, but also on access to services (Shabangu 2000:14). 
Whilst the number of people living in poverty is progressively diminishing, the distribution of income continues to grow more and more unequal. In effect, a growing number of South Africans are being lifted out of poverty, but just barely and only by the increasing provision of social transfers. Social grants are shown to have been central to poverty alleviation over the post-apartheid years. A quarter of the unemployed derives income support exclusively from the grant income of other members of their household (Leibbrandt et al. 2010:38). Social transfers can only do so much to offset South Africa's incredibly high level of gross income inequality. Without greater non-White engagement with the economy in non-menial ways, there is little hope for true empowerment or independence for the majority of the population (Asaf et al. 2010:7).

Rural and female-headed households are the poorest and their situation appears to be deteriorating. Women are far less successful than men in finding employment, so the unemployment rate for women is much higher than for men. In 2006, for example, almost 50\% of all female labour force participants were unemployed, compared to $32 \%$ of men. The majority of social grant recipients are women. In the 2006 General Household Survey, for example, almost 15\% of all women aged 15 years and older reported receiving a social grant, compared to less than $10 \%$ of men (Altbeker et al. 2010:15). The most important source of income for the unemployed in South Africa is financial support from other working members of their household (Ngepah 2011:15).

\section{The interpretive moment: Why is this going on? Why these inequalities and what are their effects on people?}

Interpretation may also be theoretical, because it gives an approximate truth and not the ultimate truth. This involves recognition of relevant particulars of specific events and circumstances, discernment of the moral ends at stake and the determination of the most effective means to achieve these ends in light of the constraints and possibilities of a particular time and place (Osmer 2008:83).

Globalisation had a great effect on inequality and poverty, and brought a feeling of powerlessness. Globalisation refers to financial and macro-economic issues. It is ideologically driven, and is often spoken of as 'competitive globalisation' (BedfordStrohm 2006:9). The economic vision underlying globalisation includes the following basic ideas (Beukes 2002:3):

- Economic growth is the only way to expand the wealth of a country and, given time, such new wealth will trickle down to everybody (the so-called 'trickle down theory').

- Job creation happens through economic growth as measured by the gross national product (GDP): ‘jobcreation through wealth-creation'.

There are two basic dimensions that underlie all forms of globalisation. The first one is the perception of reality in a global context rather than in a local or regional context - the world is visible in our living rooms. The second dimension of globalisation is global activity - we do not only perceive reality in a global context, but we also have the means to shape reality on a global scale (Bedford-Strohm 2006:9).

Two features that characterise the specifics of globalisation are new information technologies and the liberalisation of trade. Both the speed and the quality of global exchange have radically changed with the possibility of exchanging almost every desired amount of information within seconds from one part of the world to the other (Bedford-Strohm 2006:10). South Africa, in particular, is vulnerable to globalisation in the sense that, although South Africa experienced a decline in poverty (1994-2008), inequality and polarisation increased. It has been argued that globalisation-related developments in the labour market have ended up favouring better skilled workers, and therefore exacerbated inequality (Van der Berg, Burger \& Louw 2007:9).

For many years, poverty researchers (Beukes 2002; Alexander 2010; Ngepah 2011) claimed that both poverty and inequality have worsened. Rather obviously, such claims have been and will be poorly received by politicians. The government has responded by repeatedly pointing to the vast amounts spent each year on the 'social wage' (essentially housing, health, sanitation, education, electricity and water, plus social grants). This has not stilled the protests about poverty (and poor service delivery). Three grants do most of the work: the old age pension, child support grants and disability grants. Old age pensions have the greatest impact on poverty. In 2004 old age pensions raised about 1.5 million people in 600000 households over the poverty line. Wages constitute approximately two-thirds of household income in South Africa (Van der Berg et al. 2007:10).

The tension in the labour market is higher though. In addition to the racial inequality, inequality by geotype (urban versus rural) in South Africa has proven to be a leading theme in inequality studies. This bears a strong link to racial inequality, as zoning policies under the country's apartheid government forced Africans, and thus predominantly poor people, to live in allocated rural homelands. Unfortunately, youth unemployment has increased over time and remains an important characteristic of the South African poverty scenario (Leibbrandt et al. 2010:21). Despite South Africa's racially segregated past, inter-racial inequality has been declining whilst inequality within races is becoming more prominent. Young Africans still find themselves bearing the brunt of poverty and becoming increasingly dependent on social grants as they are denied employment opportunities (Leibbrandt et al. ibid:26).

During 1994-2008, the Black share of the upper middle class tripled and the Black share of the working and lower middle classes more than doubled (Altbeker et al. 2010:11). In the higher income brackets, rapid expansion of the Black middle class and Black affluent has helped to deracialise South African consumption patterns. Black people now make up about half of the growth in the upper end of the consumer market, even though they are still under-represented in this market (Van der Berg et al. 2006:29). 
Creating jobs and reducing unemployment are key economic and social challenges in South Africa. This is explicitly recognised by the South African government, which aims to halve unemployment by 2014 by removing a number of constraints on faster output and employment growth (Leibbrandt et al. 2010:2). Unfortunately, the economic growth during the first 17 years of democracy has not been equitably distributed throughout the population, making the per capita figures an inaccurate reflection of the change in well-being for the poorest segment of the population (Leibbrandt et al. ibid:8). The decrease in more recent unemployment rates is attributed to higher economic growth and lower population and labour force growth, due in all likelihood to the effects of AIDS deaths on the country (Leibbrandt et al. ibid:9).

Economic inequality leads to less trust in two ways. Firstly, high levels of inequality lead to less optimism for the future - greater pessimism means less trust. Secondly, where there is inequality, people in different economic strata will be less likely to have a sense of shared fate - they will be less likely to trust one another. If trust does lead to greater participation, then we might find indirect effects of inequality as well. High inequality results in lower levels of trust, which in turn leads to lower levels of civic engagement (Uslaner \& Brown 2005:870). Trust is a sentiment linking us to other people, to work cooperatively on common projects (Putnam 1993:170-171).

Since 2004, South Africa has been experienced a movement of local protests amounting to a rebellion of the poor. This has been widespread and intense, reaching insurrectionary proportions in some cases. On the surface, the protests have been about service delivery and against uncaring, self-serving and corrupt leaders of municipalities. Key feature has been the mass participation of a new generation of fighters, especially unemployed youths, but also school students. Many issues that underpinned the ascendency of Jacob Zuma also fuel the present action, including a sense of injustice arising from the realities of persistent inequality. Whilst the interconnections between the local protests and militant action involving other elements of civil society are limited, it is suggested that this is likely to change (Alexander 2010:32). Crime is so prevalent that it leads to emigration of South African professionals of all ethnic groups, possibly also discouraging investment and stifling growth (Dodson 2002:2).

Following ongoing and often violent protest action mainly aimed at financial inequality in the mine industry and poor service delivery on a local government level in South Africa, the situation was seen in some quarters as having the potential to escalate into a revolution, and that revolutionary potential was clearly visible. The disintegration of order is an early warning sign of a revolutionary situation. As far as mass political violence is concerned, the first stage consists of riots and street violence (Hough 2008:2). Whilst the more immediate problem is linked to the frustration of promises not kept regarding service delivery, the wider problem includes crime, the growing gap between rich and poor, and the deteriorating condition of government departments (Hough ibid:6).
Is this a time bomb? Yes, but it is not to be found at the Johannesburg Stock Exchange, or in Sandton and Houghton, or amongst the computer literates surfing the internet. It is in the townships and in the rural areas and, to some extent, in the decaying inner cities of South Africa. The majority of the poor are economic prisoners in South Africa. They cannot move over into the First World economic sector, however hard they may try (Beukes 2002:6).

\section{The normative moment: What ought to be going on? What should the church imply as norms to adjudicate and handle inequality according to its identity?}

There are three approaches to normativity: the theological interpretation; the ethical interpretation; and the good practice. The theological interpretation is informed by a theory of divine and human action. The normative task uses theological concepts to interpret particular episodes, situations or contexts, constructing ethical norms to guide our responses and learning from good practice (Osmer 2008:4). The questions to be asked are:

- What should be going on?

- What should the church imply as norms to adjudicate and handle inequality according to its identity?

In the previous sections the following questions were asked:

- What is going on? What is the extent of the economical inequality?

- Why is this going on? Why these inequalities and what are their effects on people?

From the information gathered to partly deal with these questions, a realistic answer could be that inequality and poverty will always be with us and nothing can be done to end these phenomena. These are problems that need continuous attention. They cannot permanently be resolved and therefore the only solution is to try and relieve the burden of people suffering with these problems. The church of Christ is also involved in these difficult social matters, because the church is the body of Christ and the heart and hands of Christ in this world and has to address the need of the world.

It is necessary to get a truthful starting point for the church to address this need. The best way will be to rediscover the identity of the church, because the church cannot act in the world when forsaking its own identity. The Confession of Nicea provides valuable guidelines in this respect and therefore this document and Dirkie Smit's article (2004) will be briefly explained to state the main points of the identity of the church and to examine the norms for liturgical involvement in the context of inequality and poverty.

The Confession of Nicea is one of the earliest confessions of the church (4th century) and research on part of its content can lead to the understanding of the identity of the church of the first centuries. The four marks of the church, namely 
unity, holiness, catholicity and apostolicity (as named in the Confession of Nicea), may still be determining factors for the church's missional-ecclesiastical identity. The marks are part of the church's confession, because they were born out of faith and are therefore part of a confession of the Trinity (Moltmann 1977:337). The four characteristics are not only marks, but also declarations of faith (Watson 1978:334; Clowney 1995:71; Naude 2002:50-53).

Many theologians from different fields of theology focused on the marks of the church in their research, like Küng (1976:263-359), Moltmann (1977:337-361), Du Plooy (1982: 121-184); Van Engen (1991:25-179), Scudieri (1997), Link (1999:239-262) and Dulles (1999). All of them focused on the phrase in the Confession of Nicea: 'I believe in one, holy, catholic and apostolic church'.

There is a very intimate relationship between Christ and his church: Christ as the head and the church as his body. The body is the instrument through which reconciliation is realised. The vertical reconciliation with God through Christ becomes a reality in the horizontal body. When this reconciliation is fulfilled in obedience to the calling of the church, unity, holiness, catholicity and apostolicity become a visual manifestation to the world. In that way the rule of Christ, his service to the world and the living marks of the church become concrete in the church's identity as missional. According to Van Engen (1991:56) and Floor (1995:86), it is the calling of the church as $\pi \lambda \eta \rho \omega \mu \alpha$ [in this case its unity, holiness, catholicity and apostolicity] of Christ to proclaim the love and peace of Christ.

The marks of the church as proclamations of their living faith will definitely lead to action. Because the church is one, it is the calling of the church to be one and to strive and work to show its oneness in Christ (Küng 1976:273). The church that finds its oneness in Christ is called to seek unity, proclaim unity and fight against divisions in society. The church in Christ is holy, and for this reason the members of the church are called to fight against sin and strive to become more and more mirrors of the image of Christ. The church is open in Christ for this world, and therefore it has the calling to be true to its catholic character by seeking worldwide connections with churches and work as co-workers wherever God sends his church. The church as catholic church is called to bring peace and love worldwide. The apostolic church is called to liberate the people of all nations from sin and death through the proclamation of the gospel of Jesus Christ (Moltmann 1977:339-340; Van Engen 1991:65-70).

The four marks in action can be summarised in the following way:

1. The one church of Jesus Christ must be seen as a uniting power in the world.

2. The holy church of Jesus Christ must be seen as a power of sanctification and renewal in this world.

3. The catholic church of Jesus Christ must be seen as a power of reconciliation in this world.
4. The apostolic church of Jesus Christ must be seen as a power of proclamation in this world.

The four marks define the church's identity as missionalecclesiastic and, in accordance with its identity, the calling of the church can be described in a context of inequality and poverty. The church is and must continuously strive to become the uniting, sanctifying, reconciling and proclaiming activity of Jesus Christ in the world (Van Engen 1991:70).

Smit (2004:350) states that the way people see the role of the church regarding public and social challenges (including inequality and poverty) inevitably depends on which form (gestalte) of the church they regard as primary. Smit (ibid: 350) describes six characteristics of the form or identity of the church:

- The church as congregation is called to worship and pray - with important implications for social needs and problems, including the formation and motivation of moral agents.

- These worshipping believers are called to join hands as members of congregations - making new kinds of joint activities and initiatives possible.

- Congregations are called to join one another in the koinonia of the fellowship of the church - including, within Protestantism, denominations, which makes even more comprehensive forms of activity, response and service possible.

- Denominations are called to express the even fuller unity of the church ecumenically - allowing attempts to address the more widespread and fundamental roots of the social problems, as well as to play advocacy roles on behalf of the voiceless.

- In the last resort, the church consists of individual believers, the salt of the earth, who are called to follow Jesus - practicing the Christian life in all aspects of the public sphere, politically, economically, civil society, everywhere.

- These disciples are called to join hands with one another and also with others not sharing their faith - in order to work for specific purposes and tasks in society, for example by initiating and supporting programs and forming partnership and networks.

Taken together, these six different emphases provide a fuller picture of what church really means and what the role and calling of the church, also in the face of inequality and poverty, could be (Smit 2004:350).

From the two explanations of the church's identity, three phases of involvement in society in the liturgical sense can be formulated, namely:

1. the gathering ${ }^{3}$ and sending of the local congregation

2. the liturgical responsibility with the ecumenical church

3.This article agrees with Wepener and Van der Merwe's view (2008) that there is a fourfold pattern of the worship service, namely gathering, word, bread and sending. Word and bread has been included in the discussion on gathering and, due to space limitations, the word gathering is used in a broader sense, namely during the time the congregation gathers. 
3. the possible cooperation with others not sharing the Christian faith.

\section{The strategic moment: What should be done? How can liturgical actions guide congregations in this respect?}

The strategic moment could also be referred to as the 'pragmatic task' (Heitink 1999:178). Here, strategies of action that influence events in desirable ways are formed and enacted. In this process, models of practice are formed that offer leaders a picture of the field in which they are acting. This moment also stipulates the modus operandi on particular actions and practices. The pragmatic task calls upon a leading change (Osmer 2008:176-177). The leadership style that is suggested within this context is transactional and transformational, with a focus on task competence. In accordance with the identity of the church, the following strategic guidelines may be followed.

\section{The gathering and sending of the local congregation}

The church of Christ is in South Africa the institution with the greatest influence in society. Wepener et al. (2010:65) says:

[S] urveys as well as other scholarly research have shown that in present-day South African society churches and other religious institutions are not only very well represented in terms of membership and demographic spread; they are also by far outscoring other institutions, notably government but also institutions of civil society and business, in terms of public confidence and credibility. (p. 65)

A large percentage of the more than $70 \%$ Christians in South Africa partakes in worship services with its rituals and symbols at least once a month. The acts of people gathering in worship services in church buildings, smaller structures and in the open field have the potential to influence the perceptions of society concerning inequality and poverty. A clear example is the influence of the churches for Black people in the decades before the fall of apartheid.

The identity of the church is shown in the gathering of congregations in worship services. The worship service and liturgy of Christians have two main movements, namely gathering and sending (see explanation in footnote 3) of the partakers in that service. Each of the movements takes place whilst the people present are blessed by the Lord. The believers gather, because they are called by the Holy Spirit to do so. The worship service is a threefold encounter: God takes the initiative, meets his congregation and empowers

4.The view that mainly the same three concepts come to the fore in social capital, confirm this way of handling the strategic part. Robert D. Putnam's research (2001) has shown that religious people are very active in volunteer work - they are socia capitalists. Involvement in religion is a strong predictor of voluntary work in- and outside the church. Putnam distinguishes between two types of social capital, namely bonding social capital that tends to reinforce exclusive identities, and bridging socia capital that tends to bring people together across diverse and social divisions (De capital that tends to bring people together across diverse and social divisions (De Roest \& Noordegraaf 2009:216). A third type of social capital, called linking socia capital has been distinguished by John Field and this implies reaching out to people outside the community (De Roest \& Noordegraaf ibid:216). Three concepts in socia capital come to the fore: bonding, bridging and linking. Congregations posses infrastructure as well as material and human resources that are critical components of the social capital of congregations in the process of bonding, bridging and linking (Wepener \& Cilliers 2010:419). them in that way to meet him and each other. God comes to the congregation mainly through his Word and the congregation responds to God, each other and the world. The Word from God's side and the response of the congregation in itself can be a strong testimony against inequality and poverty, and at the same time a testimony in which an alternative and energising vision for society can be presented (see Brueggemann 2001:115).

The Word of the always-present-and-speaking-God calls for a response, an answer. Through the reading and preaching of the Word, the Holy Spirit gives boldness, faith and the correct attitude to proclaim a prophetic voice to the outside world. Prophetic preaching can catch the imagination by showing an alternative, new and exciting way, for example the way in which Jesus handled people of different genders, status and income equally. At the same time, the prophetic voice must strongly reveal the sin of desiring power and money at the cost of other people. An example of this, is the teaching in Mark 10:35-45, where the disciples strive for the so-called best position in the Kingdom of Christ. Jesus reveals this attitude as sin and at the same time energised them to serve one another, like it was his calling to come and serve, and give his life for others. The inspiration and excitement lie in the fact that they could walk in the footprints of Jesus and be transformed to his likeness. Through this powerful testimony, the identity of the church as a holy church comes to the fore.

The prophetic preaching can be carried out by members who exercise the gift of prophecy. The congregation should teach each other from the Scripture reading and preaching (cf. Heb 5:12; Desilva 2000:212; Long 1995:71), and they could help each other to carry the Scripture reading and preaching further into practice. The 16th century prophecy is the joint investigation of Scripture by congregants with a special gift to apply the preached Word to concrete situations. The experience of Calvin, and others, at that time was that prophecy had a bigger influence than the most powerful sermons. Prophecy in the sense of 1 Corinthians 14 is to interpret Scripture concretely and to apply the interpretation in consoling and admonishing people in need (Hall 2003:144). A confessing response must follow upon the Word service. Two or three persons may grab the opportunity in the worship service, after the sermon has been delivered, to apply the Scripture reading and the sermon with their attitude, words and actions, focused on inequality and poverty. This will inspire the other members to do the same during the week in the different contexts that they live in. Members will then work together to draw lines from God's Word to situations in everyday life (Kim 2006:149).

Our service to God, to one another, to our neighbours and to the world around us is the result of God speaking and the congregation answering in prayers. Prayers as response is the centre of the encounter with God, because believers can bring their prayers of praise, lament, guilt, pain, invocation for the need of persons impaired by inequality and poverty, as well as intercession for people in power (like the different 
governments and also the sinful world). In the heart of the prayers of the congregation we may hear the deepest need of the world, the groaning of the creation, the questions and pain of every society and of all people (Smit 2004:352). The congregation brings in the open the sin of inequality against people treated wrongly and impoverishing of the weak at the cost of the selfishness of the people in power. The congregation echoes the voices of those in pain in the presence of God through lament. In prayer, the congregation speaks out on behalf of these people to let their suffering be heard, and brings their joy of unexpected relief from difficult circumstances to the forefront. The singing congregation is taught through melody and words how to view the need of their world through the eyes of Christ and the enlightenment of the Holy Spirit. In the same congregation there may be the so-called haves and have nots, and some of the members may suffer under the cross of inequality and poverty - in their case, prayers and songs are of immeasurable importance. Giving people the opportunity to articulate their experience in, for example acts of lament and praise has spiritual value (Wepener \& Cilliers 2006:793). The pain of these people is mentioned in the Psalms and other spiritual songs.

The worship service as koinonia, as a space to give the love of Christ to one another, can be a preparation for every member to give the same love to the neighbour in need because of the phenomenon of inequality. The identity of the church as catholic is revealed when the church as reconciled community lives within an atmosphere of love. As a community living in love with one another, they will trust one another and this will lead to the creation of small service groups that may be a voice against inequality practices as well as a hand to relieve poverty. The exposure of members in the safe comfort zone of the congregation to people with different personalities and viewpoints will give boldness to proclaim the righteousness and example of Christ in a context where there are heated arguments on what the reasons and the resolutions are for inequality and poverty.

The worship service of the congregation is continued in the everyday life. The transition from the formal worship service to the worship service of everyday life is connected by the so-called 'sending away blessing'. Whilst receiving God's blessing with his life-giving words that are channelled into the heart of every partaker in the worship service, the believer enter his or her own context. The identity of the church as apostolic community becomes noticeable through the proclaiming power that everyone uses to testify with or without words.

These believers that are blessed will be held responsible for the way they live the liturgy of everyday life. They will, according to Matthew 25:31-46, be asked if they did the will of the Father; if they loved Jesus with heart and hands by helping those who suffered - the sick, the poor, the prisoners that God has brought on their path. In that way the world will know that they are Jesus' disciples. The followers of Christ are able to contribute to the public opinion in society and to take the lead to change the viewpoints on inequality and poverty. The moral quality of any society is mirrored in the manner in which the weak and the victims are cared for. When the present public life is characterised by a culture of greed and of fighting for power, the believers have the calling to, through exercising the gift of prophecy, create a culture of care, service and providing help (Smit 2004:359).

\section{The liturgical responsibility with the ecumenical church}

The church worldwide is one body of Christ and therefore local churches and church societies are bound together. For this reason, local churches and church societies need one another and the local church that ignores this, is not a complete church (Strauss 2005:298). Congregations belong to one another. In many cases today the simple truth of the gospel of fraternal unity is neglected and the result is that those congregations become self-centred and self-satisfied, and they focus only on their own activities. There are also practical reasons for working together in all the concentric circles. It is an enormous task to combat inequality and to give people an alternative vision - too great for one single congregation. If one congregation tries to fulfil this task on its own, no breakthrough will be made and the need of people will become bigger (Smit 2004:356).

The churches in the New Testament era showed that the unity between them was visible, lively and active. A liturgical act in the first congregations serves as an example. The congregations planted through of the missionary work of Paul collected money for the poor members of the Jerusalem congregation. Through the centuries, many churches were the hands and feet of Christ in a context of social, cultural, traditional and political differences. In other religious groups these differences divided people into different castes and statuses (Smit 2004:355). The Christian church has the calling to live out its unity so that the world may know that God sent Christ to reconcile the world with him (Jn 17:23). The prayer of Christ teaches that the characteristic of unity, made visible by deeds of love between Christians, is a testimony in the world and a rejection of selfish independentism (Moses 2000:203).

The liturgical responsibility of the ecumenical church in respect of inequality and poverty can be described in three concentric circles. In the middle are the churches in the same neighbourhood of the same church family, but also from other denominations. The next circle includes churches in the same country of the same denomination or with the same confession. The third circle includes churches with differing confessions and liturgies in the same country. This circle is also worldwide between churches with the same or different confessional foundations. The liturgical responsibility will probably differ between churches in the different circles of ecumenical relationships.

In case where churches are neighbours, it is often a showcase of the inequality in that specific society. In neighbouring residential areas, there are rich and poor congregations and 
congregational members. There are big differences in social status. These social dimensions have the benefit that believers learn to care for one another, to share each other's sorrows, and through this spiritual and material caring, a material infrastructure and resources are formed as a by-product. Those dimensions of ritual (like the Eucharist) that are beneficial for open, friendly ritual spaces can make a contribution towards the establishment of an infrastructure where the poor can receive a voice as one example of such a by-product. In such a safe, friendly space, the poor and marginalised can also contribute to discussions, lead in prayer and develop their civil skills in the process (Wepener \& Cilliers 2006:795). The exposure to one another in joint worship services may better the mutual understanding of the circumstances the other lives in and also lead to communal prayers for the illumination of inequality and poverty. In praying with one another, the believers from different circumstances will hear the pain and joy in the prayers of the other, and in that way bring lament and confession of guilt before God.

These congregations of different backgrounds, cultures and languages may celebrate the Holy Communion as a symbol of reconciliation in Christ and a symbol of unity. The Eucharist, to quote but one example, presents the story of the suffering of the people in a symbolic way, and in doing so, not only reinterprets their story, but reconfigures their reality and generates new spiritual endurance (Wepener \& Cilliers 2006:788). In the New Testament era, the Holy Communion was connected with the so-called 'love meals'. The inequality that the partaking in the meals revealed in the Corinthian congregation may be an example and warning for churches to fight against the sin of greed (as result of the view that members are not equal) as well as the injustice to the poor. On the other hand, the Holy Communion connects people through a communal meal and so provides a space where believers from different cultures and income can experience one another as brothers and sisters, as an alternative community marked by mutual love and, as such, it is a living sermon to the outside world (Old 2002:116).

Churches in the same greater city or town, but from different denominations, may in the liturgical sense come to action by means of joint prayers. They can testify against the misuse of power and money at the cost of others. Churches in such a community may deliver their protest in a way that will be an example to the community by protesting nonviolently, in comparison to the destruction of property and lives - in many cases the result of violent protests. Instead of destruction, the local churches can plan for daily provision of food and provide guidelines for a liturgy to follow whilst unfortunate people are gathered to receive the food.

In the broader concentric circle, churches in the same country and of the same denomination can give testimony, spreading from persevering prayers, against the government of the day. The testimony will focus on the government's neglect to eliminate inequality, unemployment and corruption. All the churches of different denominations can decide on a day of prayer, asking the Lord to end all of these practices. An example of a Christian community that perseveres in prayer can be found in East Germany in the previous century. Believers from all churches prayed on a specific time and day of the week for the end of the oppressing communist regime and the Lord answered their prayers. Inequality is of enormous magnitude in South Africa and is experienced in every population group. The churches may call on a day of humiliation to confess guilt and pray for the forgiveness from the sin of inequality at the cost of our fellow countrymen (see Neh 1:8; Boda 2003:60). Symbols speak a clear language and churches in every town and city could get a creative opportunity to portray this sin in symbols as well as the alternative of a loving and giving community. Symbolically, it could be a very clear message if every church in the country on one specific Sunday make their love offering available for unemployed people, especially to become entrepreneurs. Churches may also help the people affected by inequality by training them in basic life skills and ethical norms.

The church of Christ is one, and the ecumenical calling of the church is therefore very important. The ecumenical church of the world gave evidence that the prophetical testimony and prophetical protests were powerful instruments to help dismantle apartheid (Vroom 2003:159). This same voice may be effectively applied in South Africa and worldwide against the abuse of power and the financial exploitation of others. The church in the world is the voice of the voiceless by defending the rights of those who are rejected and despised. The ecumenical church can make valuable contributions in public debates on human rights, morality, crime, violence against women and children, poverty, education, AIDS, et cetera (Smit 2004:358).

In all the ecumenical responsibilities, the church must remain true to the marks of identity, namely unity, holiness, catholicity and apostolicity.

\section{The possible cooperation with others not sharing the Christian faith}

The need and problems caused by inequality and poverty are in most instances too complex, ongoing and difficult to resolve. Therefore, it is necessary to take hands with any institution that is concerned with this inequality and poverty. The civil society has an important role to play and churches, according to their own identity, may work together with non-government organisations, business and private sectors, and also other faith groups (Smit 2004:360).

\section{Conclusion}

Liturgically, it is not possible for churches to give up their identity and worship in cooperating with non-Christian groups. There is space for every group to respond to the need that they experience in common. They could agree to take action on the same day, according to their own identity, by making the government and the South African population aware of the need and of the lack of taking affirmative action. On this day, the Christian community may use the Word, preaching, prayers and their symbols and rituals to stress the need to plan for better action from all sectors of the society. 


\section{Acknowledgements Competing interests}

The author declares that he has no financial or personal relationship(s) that may have inappropriately influenced him in writing this article.

\section{References}

Alexander, P., 2010, 'Rebellion of the poor: South Africa's service delivery protests - A preliminary analysis', Review of African Political Economy 37(123), 25-40. http:// dx.doi.org/10.1080/03056241003637870

Altbeker, A., Hay, M. \& Bernstein, A., 2010, 'Poverty and inequality: Facts, trends, and hard choices', edited proceedings of a Round Table convened by the Centre for Development and Enterprise, UCT, Cape Town. (With input from prof. L. Schlemmer.)

Asaf, Z., Cato, N., Jawoko, K. \& Rosevear, E., 2010, 'Promise unmet? Addressing inequality in post-apartheid South Africa', Constitutional design for divided societies: Theory and cases, pp. 1-11, University of Toronto Press, Toronto.

Bedford-Strohm, H., 2006, 'Public theology and the global economy. Ecumenical social thinking between fundamental criticism and reform', Nederduitse Gereformeerde Teologiese Tydskrif 48(1\&2), 8-24.

Beukes, P., 2002, 'Life before death - Socio-economic justice issues and mission. The economy, poverty and the church', in J.J. Kritzinger (ed.), Mission in the new SA, pp. 1-14, Pretoria University, Pretoria.

Boda, M.J., 2003, 'The priceless gain of penitence: From communal lament to penitential prayer in the 'exilic' liturgy of Israel', Horizons in Biblical Theology 25(1), 51-75. http://dx.doi.org/10.1163/187122003X00033

Brueggemann, W., 2001, The prophetic imagination, Fortress Press, Minneapolis.

Clowney, E.P., 1995, The church, InterVarsity Press, Illinois.

De Roest, H.P. \& Noordegraaf, H., 2009, '"We learned it at our mothers' knees". Perspectives of churchgoing volunteers on their voluntary service', Reformed World 59(3), 213-226.

Desilva, D.A., 2000, Perseverance in gratitude: A socio-rhetorical commentary on the epistle to the Hebrews, Eerdmans, Grand Rapids. PMCid:PMC18822

Dodson, B., 2002, 'Gender and the brain drain from South Africa', The Southern African Migration Project, Cape Town. (Migration Policy Series \#23.)

Du Plooy, A.leR., 1982, 'Kerkverband. 'n Gereformeerd-kerkregtelike studie', ThD thesis, Church Polity, PU vir CHO

Dulles, A., 1999, 'The church as one, holy, catholic, and apostolic', Evangelical Review of Theology 23(1), 14-28.

Floor, L., 1995, Efeziërs: Een in Christus, Kok, Kampen.

Hall, D.R., 2003, The unity of the Corinthian correspondence, T\&T Clark, London.

Heitink, G., 1999, Practical theology: History, theory, action domains, transl. R. Bruinsma, Eerdmans, Grand Rapids.

Hough, M., 2008, 'Violent protest at local government level in South Africa: Revolutionary potential?', Scientia Militaria: South African Journal of Military Studies 36(1) $1-14$.

Kim, C.H., 2006, 'Prophetic preaching as social preaching', Evangelical Review of Theology 30(2), 141-151.

Küng, H., 1976, The church, 6th edn., T\&T Clark, London.

Leibbrandt, M., Woolard, I., McEwen, H. \& Koep, C., 2010, Employment and inequality outcomes in South Africa, Southern Africa Labour and Development Research Unit (SALDRU) and School of Economics, University of Cape Town, Cape Town.
Link, C., 1999, Toward the future of Reformed Theology, Eerdmans, Grand Rapids.

Long, T.G., 1995, Hebrews: A Bible commentary for teaching and preaching, T\&T Clark, London.

Moltmann, J., 1977, The church in the power of the Spirit, SCM Press, London.

Moses, J.A., 2000, 'Dietrich Bonhoeffer's prioritization of church unity (Oekumene)' The Journal of Religious History 24(2), 196-212. http://dx.doi.org/10.1111/14679809.00109

Nattrass, N. \& Seekings, J., 2010, 'State, business and growth in post-apartheid South Africa. Discussion Paper Series, Thirty Four', IPPG Discussion Papers, viewed 14 Africa. Discussion Paper Series, Thirty
February 2013, from www.ippg.org.uk

Ngepah, N., 2011, 'Production, inequality and poverty linkages in South Africa', Economic Research Southern Africa (ERSA) Working Paper, pp. 1-18, Energy Research Centre (ERC), University of Cape Town, Cape Town.

Naude, P., 2002, 'Confessing Nicea today? Critical questions from a South African perspective', Scriptura 79, 46-53.

Old, H.O., 2002, Worship: Reformed according to Scripture, John Knox Press, Louisville, $\mathrm{KY}$.

Osmer, R.R., 2008, Practical theology: An introduction, Eerdmans, Grand Rapids.

Putnam, R.D., 1993, Making democracy work: Civic traditions in modern Italy, Princeton University Press, Princeton, NJ.

Putnam, R.D., 2001, Bowling alone: The collapse and revival of American community, Simon \& Schuster, New York.

Shabangu, G.M., 2000, Community participation and planning in poverty alleviation, University of Witwatersrand, Johannesburg.

Scudieri, R.J., 1997, 'The Creed of Nicea as a paradigm for mission', Missio Apostolica 5, 66-77.

Smit, D.J., 2004, 'Oor die kerk en maatskaplike uitdagings in ons land', Nederduitse Gereformeerde Teologiese Tydskrif 45(2), 350-362.

Strauss, P.J., 2005, 'Watter sake hoort by meerdere vergaderings?', In die Skriflig 39(2), 293-309. http://dx.doi.org/10.4102/ids.v39i2.386

Uslaner, E.M. \& Brown, M., 2005, 'Inequality, trust, and civic engagement', American Politics Research 33, 868-894. http://dx.doi.org/10.1177/1532673X04271903

Van der Berg, S., Burger, R. \& Louw, M., 2007, 'Poverty and distribution trends in an era of globalization', World Institute for Developing Economics Research, University of Stellenbosch, Stellenbosch. PMid:17212737

Van der Berg, S., Burger, R., Burger, R., Louw, M. \& Yu, D., 2006, 'Trends in poverty and inequality since the political transition', Development Policy Research Unit. Working Paper 06/104, University of Stellenbosch, Stellenbosch.

Van Engen, C., 1991, God's missionary people, Baker Books House, Grand Rapids. PMid:1812913

Vroom, H.M., 2003, 'On being reformed', in C. Lienemann-Perrin, H.M. Vroom \& M. Weinrich (eds.), Reformed and ecumenical: On being Reformed in ecumenical encounters, pp. 153-167, Rodopi, Amsterdam.

Watson, D., 1978, I believe in the church, Hodder \& Stoughton, London.

Wepener, C. \& Cilliers, J., 2006, 'Research on liturgy and the generation of social capital in contexts of poverty in South Africa', Nederduitse Gereformeerde Teologiese Tydskrif 47(3\&4), 786-798.

Wepener, C. \& Cilliers, J., 2010, 'Ritual and the generation of social capital in contexts of poverty', in I. Swart, H. Rocher, S. Green \& J. Erasmus (eds.), Religion and socia development in post-apartheid South Africa, pp. 417-430, Sun Press, Stellenbosch.

Wepener, C. \& Van der Merwe, I.J. (eds.), 2008, Ontdekkings in die erediens, Lux Verbi, Wellington. PMid:18471835

Wepener, C., Swart, I., Ter Haar, G. \& Barnard, M., 2010, 'The role of religious ritual in social capital formation for poverty alleviation and social development: Theoretical and methodological points of departure of a South African exploration' Religion and Theology 17(1\&2), 61-82. http://dx.doi.org/10.1163/157430110X517924 